\title{
International non-governmental actors in HIV/AIDS prevention in China
}

\author{
Feng Shi WU* \\ Department of Government and Public Administration, Chinese University of Hong Kong, Shatin, N.T., Hong Kong SAR, \\ China
}

\begin{abstract}
International non-governmental organizations were among the first international actors that responded to the emergence of AIDS crisis in China. Since 1994, the number of international non-governmental organizations and charitable foundations working in AIDS related issue areas in China has grown steadily and substantially. Despite their organizational differences, most of these non-governmental actors present the characteristics of independent mission, localized practice and diverse working focus. Even though they are constrained by financial and other factors compared with multilateral and bilateral official assistance agencies, they have still played a unique role in fighting against AIDS in China as technical experts, public educators, and civil society supporters.
\end{abstract}

Keywords: AIDS, China, NGO.

\section{INTRODUCTION}

This research examines a group of international nongovernmental organizations (NGOs) and private foundations that have worked and/or are still working in HIV/ AIDS prevention related issue areas in China. Main characteristics of this transnational voluntary community and a few representative organizations are highlighted in order to further explain the role played by this group. Though secondary resources are occasionally used, results and interpretations presented below are mostly drawn upon in-depth interviews and participatory observations in the past two years [1-8].

\section{QUICK RESPONSE AND GRADUAL GROWTH}

International NGOs responded to the potential spread of HIV virus in China shortly after the news of a large number of Chinese drug users tested positive became known in 1992. For example, Red Cross Australia initiated negotiations with Yunnan government regarding AIDS prevention in 1994, two years before UNAIDS China office opened in Beijing. In 1995, Save the Children U.K. moved its China office to Yunnan and implemented its first AIDS related project in the province. The number of international NGOs directly involved in HIV/AIDS prevention in

*Correspondence: Feng Shi WU

Tel: 852-26097541; Fax: 852-26035229;

E-mail: wufengshi@cuhk.edu.hk.
China has since grown steadily. Many private foundations who have had long-time experience working in China, e. g., the Ford Foundation and Asia Foundation, also added AIDS related programs in the late 1990s. Year 2003 saw a considerable increase in NGO numbers due to the positive changes in governmental policies. By the end of 2004, there are over 50 international NGOs and private foundations actively promoting HIV/AIDS prevention in China. (For the names of all the international NGOs and private foundations studied in this research see Appendix.)

This research surveyed the starting years of 32 main international health NGOs that have operated AIDS related projects in China, and found that even though most of them only started working in the AIDS field recently, many have been working in public health or other fields of social welfare in China since the 1980s. (Fig. 1) For example, as early as in 1979, an American NGO, PATH (Program for Appropriate Technology in Health), accepted the invitation from the Chinese government to provide technical consultation for maternal and reproductive health in the country. Today, PATH has provided HIV/AIDS prevention training to adolescence and migrant workers in various parts of China. Therefore, this community seems to be "new" to China, while many of them are actually old friends of the country.

INDEPENDENT MISSIONS, LOCALIZED PRACTICE AND DIVERSE PROGRAMS

This community of international NGOs (as well as fund- 


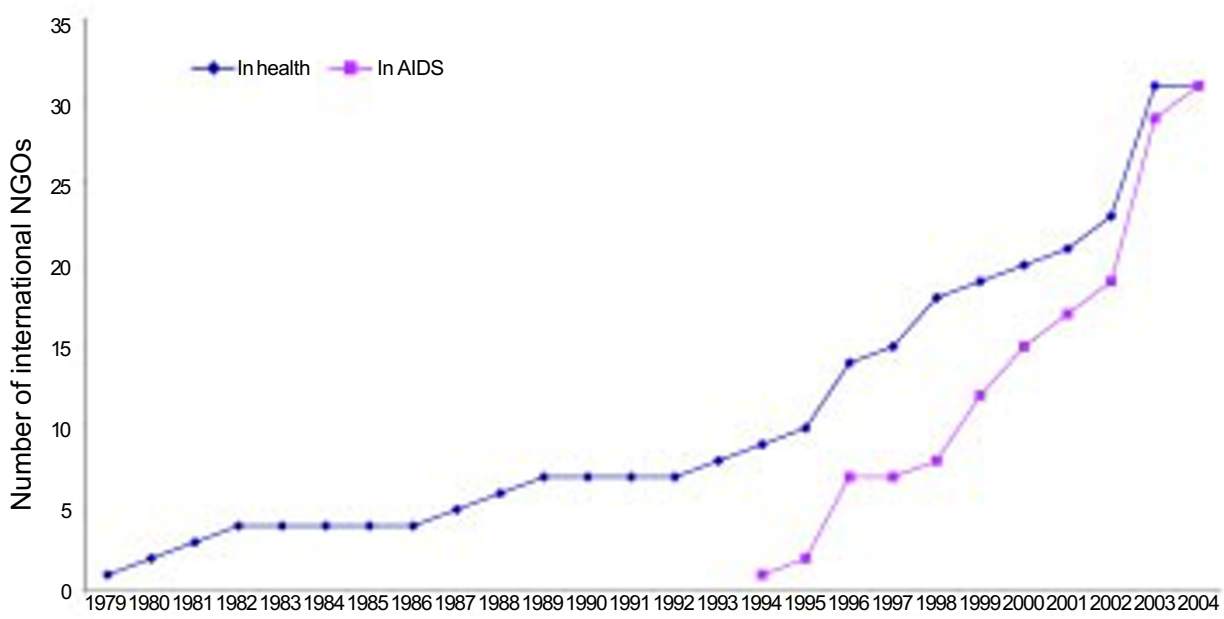

Fig. 1 Growth of international NGOs working in health and AIDS prevention in China. Among the 32 focused international NGOs, 8 worked in non-AIDS yet health related fields in China before 1994. Even after 1994, a number of international NGOs implemented their programs in non-AIDS related issues before they launched AIDS prevention initiatives.

ing organizations) is very diverse in terms of their organizational structures, personnel composition, financial resources, and working philosophies. Some are truly transnationalized, operated by professionals in all continents of the world e.g., Médecins sans Frontières (MSF). Some are small-scaled run by one or a few overseas Chinese, e.g., Chi Heng Foundation in Hong Kong and the AIDS Relief Fund for China in the U.S. However, majority of them share three characteristics: first, they came to China on independent missions; second, they have established networks and working base inside China and fairly localized their practices by recruiting Chinese staff members and implementing project directly with Chinese citizens; and, third, except few, they mostly are not AIDS exclusive organizations. Even if they focus on AIDS related issues, they have diversified their targeted populations and expanded their work to various geographic locations.

Fig. 2 below illustrates the above three characteristics based on the survey data of 32 main international NGOs studied in this research. Only three international NGOs are essentially implementing agencies of bilateral or multilateral projects. For example, Family Health International established its office in China in 2003 as the chief coordinating agency to implement the U.S. Agency for International Development's Mekong Region Health Project. Some international NGOs have gradually evolved into independent entities, although they first arrived in China as technical advisors for U.N. agencies, such as Marie Stopes China. Independent mission means that international NGOs usually have their own organizational philosophies and op- erational principles (which sometimes could be very detailed and specific), and they have to follow, or at least, not go against, such principles in their practices. In other words, they can be more persistent and precise about their project goals and approach in contrast with their bilateral and multilateral counterparts.

24 of the 32 surveyed international NGOs have established their local offices/bases in China. Among the eight NGOs that have not obtained a physical presence in China, a few have formed strong personal connections with Chinese governmental agencies and social organizations. For example, the Aixin Foundation, registered in Maryland, U. S., was founded by a group of American Chinese professionals, who have considerable personal ties and contacts in China in the field of public health and AIDS prevention. They sponsored a senior Party School instructor to obtain trainings in the U.S. in 2003, who later became a key advocate of AIDS prevention policies to Chinese provincial leaders. Local offices, teams, and personal connects signify the work and influence of international NGOs at the grassroots level.

While seven international NGOs limit their work by targeting a particular group of people within a specific geographic location, the rest majority aim at various high risk populations, and/or in multiple locations. At the global level, there is emerging a trend to link AIDS relief, prevention and treatment together and to take a multi-sectoral approach. Consequently, international NGOs in the field in China also tend to work in a comprehensive way even when dealing a defined group of people or problem. For example, MSF Belgium has opened a HIV/AIDS clinic in 


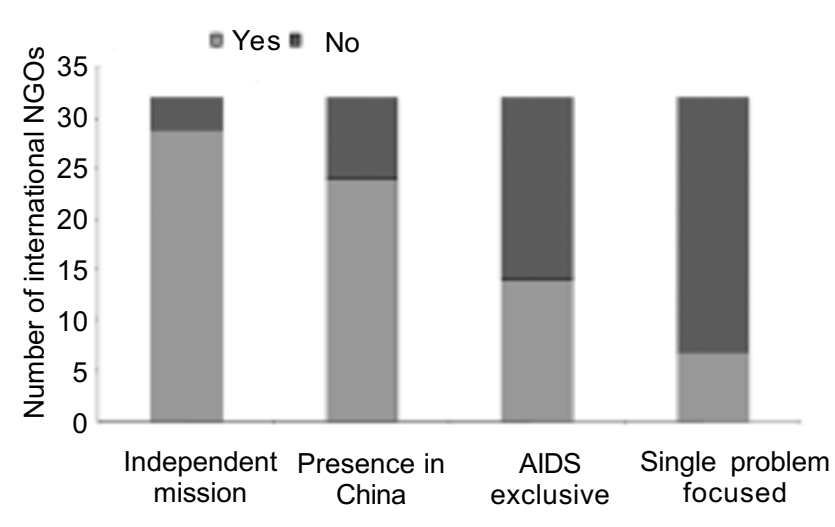

Fig. 2 General characteristics of international NGO community in AIDS prevention in China. Among the 32 focused international NGOs, 29 have developed independent programs, 24 have established physical presence inside mainland China, 14 are AIDS exclusive organizations, and 7 are single problem focused.

Xiangfan, Hubei province since mid-2003. In addition, they have also provided a large number of trainings to various targeted groups including medical professionals, patients, and the youth.

\section{THE ROLE OF INTERNATIONAL NGOS: EXPERT, PUBLIC EDUCATOR AND CIVIL SO- CIETY SUPPORTER}

Compared with governmental assistance programs, the total financial and human resources of the international NGOs community looks slim. Nevertheless, partially due to the above three distinctive features and advantages, they have played a unique role in the whole picture of AIDS prevention in China. First, recognized as specialists and experts by the Chinese government and public, international NGOs have provided considerable technical and financial support to Chinese health institutions, schools and other related organizations. For example, collaborating with Yunnan Provincial Health agencies, the Health Unlimited has provided AIDS related training to village doctors combined with their traditional expertise in maternal health training. More well-known examples in this category also include the collaboration between the Aaron Diamond AIDS Research Center in New York and Chinese central health agencies.

Second, despite various obstacles, international NGOs endeavor to reach the Chinese public directly and provide them with newest information of HIV/AIDS policies and treatment, such as the China AIDS Info., a Hong Kong NGO yet based in Beijing. More importantly, a few international NGOs have been persistently reaching out to the worst hit regions beyond major cities, and most marginalized high risk populations (particularly commercial sex workers, gay communities, and drug users). Through continuous communication and interaction with local authorities, several Hong Kong and western NGOs have started education and relief work in Hennan province. A few have sustained contacts with rural HIV/AIDS patients in many remote areas of Yunnan, Guangxi, Sichuan, and Xinjiang Autonomous Region. Some target in particular the social groups that are normally overlooked by large donor agencies. For example, DKT International, a Washington, D.C. based charitable organization that implements social marketing programs in nine countries, promoting condom use among migrant workers in China.

Last not least, international NGOs and private foundations provided crucial support to Chinese grassroots, and/ or voluntary social groups to further AIDS prevention goals. Ford Foundation started its reproductive health program in recently years, and has support many of the key Chinese academics, experts and activists in the field of AIDS. Both the Berry and Martin's Trust (U.K.) and the AIDS Relief Fund for China (U.S.) believes in "Small is Beautiful", and made particular effort to search for grassroots groups and help them to consolidate their voluntary relief and care work for AIDS patients and their families. Chinese civil society is still at a nascent stage and most Chinese social groups lack of self-capacity, international non-governmental actors are more willing to take risk in supporting them compared with other external assistance agencies. In a way, their AIDS related assistance has achieved double meaning fruits.

International NGOs are certainly an indispensable component of the whole collective effort to alleviate the pressure posed by rapid increase in HIV infection in China. This article serves only as a sketch to outline the main characteristics of this community. For the readers and policy makers, it is necessary to link the above descriptions and analysis back to the large picture of China's domestic situations, multiple players, and nested institutional structures.

\section{ACKNOWLEDGEMENTS}

I acknowledge the essential support from all my interviewees, without which this research would not be possible. I also thank Prof. Ken CONCA, Prof. Margaret PEARSON, Dr. Richard ZHAO, Dr. Yongkai WENG, Mr. Andrew THOMPSON, and Mr. Odilon COUZIN for sharing their insight.

\section{REFERENCES}

1 HIV and AIDS in China: The emerging response from UK based international development NGOs, London: U.K. Consortium on AIDS and International Development, 2002. 
2 A chronology of AIDS crisis in China, Maryland: Aixin Foundation, 2004.

3 China HIV/AIDS chronology, China AIDS Survey, 2004.

4 HIV/AIDS in China (Extractions from Country Reports on $\mathrm{Hu}-$ man Rights Practices), Washington, D.C.: U.S. State Department, 2004.

5 UNAIDS Theme Group on HIV/AIDS in China, Annual reports 1998-2004.

6 Cohen J. HIV/AIDS in China. Poised for takeoff? Science 2004; 304:1430-32.

7 Gill B, Chang J, Palmer S. China's HIV crisis. Foreign Affairs Mar/Apr2002; 81, 2:96-110.

8 Thompson A. China confronts HIV/AIDS. Washington, D.C.: Population Reference Bureau, 2005.

\section{APPENDIX}

International NGOs and Foundations Working in AIDS Prevention in China Studied in This Paper

\section{International NGOs}

Chi Heng Foundation (Hong Kong)

China AIDS Info. (Hong Kong)

Hong Kong AIDS Foundation

Harmony Home Association (Taiwan)

Oxfam Hong Kong

Salvation Army Hong Kong

World Vision Hong Kong

Aaron Diamond AIDS Research Center (U.S.)

Aixin Foundation (U.S.)

Australian Red Cross Society (Australia)

Daytop (U.S.)

DKT International (U.S.)

Family Health International (U.S.)
Futures Group Europe

Helping AIDS in Resource Poor Areas (HARPA) (U.S.)

Health Unlimited (U.S.)

International Federation of Red Cross and Red Crescent

Societies (Switzerland)

International HIV/AIDS Alliance (U.K.)

International Planned Parenthood Federation

Macfarlane Burnet Centre (Australia)

Marie Stopes (U.K.)

Médecins Sans Frontières (Doctors without Borders)-

Belgium

Médecins Sans Frontières France

Médecins du Monde (Doctors of the World) (France)

Voluntary Service Overseas (U.K.)

PATH (U.S.)

Population Services International (U.S.)

Project Hope (U.S.)

Rotary Club (U.S.)

Save the Children (U.K.)

U.S.-China AIDS Alliance Foundation (U.S.)

Yale-China Association (U.S.)

\section{International charities and foundations}

AIDS Relief Fund for China (U.S.)

Asia Foundation (U.S.)

Barry and Martin's Trust (U.K.)

Bill and Melinda Gates Foundation (U.S.)

China AIDS Orphan Foundation (Minnesota, U.S.)

Clinton Foundation (U.S.)

Ford Foundation (U.S.)

Misereor (German Catholic Charity)

Operation Blessing (Taiwan Christian Church) 